\title{
Uremia causes premature ageing of the T cell compartment in end-stage renal disease patients
}

\author{
Ruud WJ Meijers ${ }^{1 *}$, Nicolle HR Litjens ${ }^{1}$, Elly A de Wit ${ }^{1}$, Anton W Langerak ${ }^{3}$, Ashley van der Spek ${ }^{3}$, Carla C Baan², \\ Willem Weimar ${ }^{2}$ and Michiel GH Betjes ${ }^{1}$
}

\begin{abstract}
Background: End-stage renal disease (ESRD) patients treated with renal replacement therapy (RRT) have premature immunologically aged T cells which may underlie uremia-associated immune dysfunction. The aim of this study was to investigate whether uremia was able to induce premature ageing of the $T$ cell compartment. For this purpose, we examined the degree of premature immunological T cell ageing by examining the $T$ cell differentiation status, thymic output via T cell receptor excision circle (TREC) content and proliferative history via relative telomere length in ESRD patients not on RRT.

Results: Compared to healthy controls, these patients already had a lower TREC content and an increased T cell differentiation accompanied by shorter telomeres. RRT was able to enhance $C D 8^{+} \mathrm{T}$ cell differentiation and to reduce $C D 8^{+} T$ cell telomere length in young dialysis patients. An increased differentiation status of memory $C D 4^{+}$ $T$ cells was also noted in young dialysis patients.

Conclusion: Based on these results we can conclude that uremia already causes premature immunological ageing of the T cell system and RRT further increases immunological ageing of the CD8 ${ }^{+} \mathrm{T}$ cell compartment in particular in young ESRD patients.
\end{abstract}

Keywords: Ageing, CD28null, End-stage renal disease, Renal replacement therapy, T lymphocytes, Uremia

\section{Background}

Loss of renal function is related to impaired function of the $\mathrm{T}$ cell-mediated immune system. Changes in $\mathrm{T}$ cell subsets and function may underlie this effect [1,2]. Clinical consequences of this $\mathrm{T}$ cell-mediated immune dysfunction are a reduced efficiency of vaccination [3,4], an enhanced susceptibility for infectious diseases [5] and an enchanced risk for developing auto-immune diseases and tumors [6].

$\mathrm{T}$ cells leave the thymus as naïve cells. Upon encountering of antigens presented by antigen presenting cells, naive $\mathrm{T}$ cells will differentiate into effector $\mathrm{T}$ cells and eventually only a fraction of these will develop into memory $\mathrm{T}$ cells. The expression of (chemokine C-C motif receptor 7) CCR7 and CD45RO can be used to distinguish between the different $\mathrm{T}$ cell subsets, i.e. naïve $\left(\mathrm{CD} 45 \mathrm{RO}^{-} \mathrm{CCR} 7^{+}\right)$, central memory $\left(\mathrm{CM}, \mathrm{CD} 45 \mathrm{RO}^{+}\right.$

\footnotetext{
* Correspondence: r.meijers@erasmusmc.nl

${ }^{1}$ Department of Internal Medicine, section Nephrology and Transplantation, Erasmus Medical Center, Rotterdam, the Netherlands

Full list of author information is available at the end of the article
}

$\mathrm{CCR}^{+}$, able to home into lymphoid tissues), effector memory (EM, CD45RO ${ }^{+} \mathrm{CCR} 7^{-}$, exerting direct effector functions) and the more terminally differentiated effector memory CD45RA ${ }^{+}$(EMRA, CD45RO-CCR7 ${ }^{-}$, high in effector function) subset $[2,7,8]$. In addition, the loss of cell surface CD28 expression identifies more differentiated $\mathrm{T}$ cells [9].

During ageing in healthy individuals, the thymic output of new naïve $\mathrm{T}$ cells reduces due to the involution of the thymus. Absolute $\mathrm{T}$ cell numbers are largely conserved by homeostatic proliferation of both naïve and memory $\mathrm{T}$ cells but eventually this leads to a reduced population of naïve $\mathrm{T}$ cells and a relatively preserved population of memory $\mathrm{T}$ cells [10]. Elderly individuals have a marked decrease in naïve $\mathrm{T}$ cells, a decline in $\mathrm{CD} 4 / \mathrm{CD} 8$ ratio and a relative increase in the number of differentiated memory T cells lacking CD28 [10-12].

The thymic output of new naïve $\mathrm{T}$ cells can be determined by measuring the $\mathrm{T}$ cell receptor excision circles (TRECs)[13]. These TRECs are small circular DNA episomes that are formed during rearrangement of the $\mathrm{T}$ 
cell receptor (TCR) genes in T cells that are present in the thymus. These TRECs are not replicated and therefore diluted with every cell division. Another hallmark of ageing is the reduction in telomere length $[14,15]$. Telomeres are small DNA sequences located at the end of a chromosome and with increasing age they become shorter due to the inability of telomerase to elongate these DNA sequences upon division. Together, TREC content and telomere length reflect the thymic output and replicative history of T cells and may provide a valuable tool to estimate the immunological age of the $\mathrm{T}$ cells within an individual.

Using these ageing parameters, the $\mathrm{T}$ cell system of a dialysis patient shows severe $\mathrm{T}$ cell ageing and resembles that of a 20-30 year older healthy individual [1]. This premature ageing of the $\mathrm{T}$ cell system probably underlies the uremia-associated immune defect in dialysis patients. However, it is not known whether the $\mathrm{T}$ cell system of ESRD patients not on renal replacement therapy (RRT) shows a similar degree of immunological ageing and to what extent this is influenced by RRT.

In this cross-sectional study, we have analyzed the $\mathrm{T}$ cell ageing parameters in ESRD patients who are not on RRT and compared this to healthy individuals on one hand, and patients treated with RRT (i.e. hemodialysis or peritoneal dialysis) on the other hand.

\section{Results}

T cell ageing parameters in hemodialysis and peritoneal dialysis patients

Initially, T cell numbers and ageing parameters of ESRD patients treated with hemodialysis were compared to peritoneal dialysis patients but no statistically significant differences were observed. Therefore, the data of these two RRT groups were combined for comparison with the data of ESRD patients not on RRT (non-RRT group). The clinical and demographic characteristics of patients and healthy controls are shown in Table 1. Compared to the old ESRD patient group, the young patients showed a different distribution of underlying kidney diseases (less frequently hypertensive nephropathy and more frequently reflux nephropathy). Moreover, the young RRT group had a longer history of dialysis treatment than the old RRT group. However, type of underlying kidney disease and dialysis vintage were not significantly associated with any of the ageing parameters measured.

\section{$\mathrm{CD}^{+} \mathrm{T}$ cell differentiation is increased in ESRD patients but marginally affected by RRT}

The young and old non-RRT groups had significant lower numbers of $\mathrm{CD}^{+}{ }^{+} \mathrm{T}$ cells when compared to agematched Healthy Controls (HC). In the young nonRRT group, a lower absolute number of memory $\mathrm{T}$ cells and comparable numbers of naïve $\mathrm{T}$ cells were observed when compared to that of age-matched HC. Especially in the old non-RRT group, the $\mathrm{CD}^{+} \mathrm{T}$ cells were shifted towards the memory phenotype with significant less naive $\mathrm{T}$ cells when compared to age-matched $\mathrm{HC}$ (Figure 1A). The $\mathrm{CD}^{+}$memory compartment of the non-RRT group contained significantly $(\mathrm{p}<0.01)$ lower numbers of central memory $\mathrm{T}$ cells, resulting in a relative increase of more differentiated effector-memory $\mathrm{T}$ cells when compared tot that of age-matched HC (Figure 1B). No differences were observed if RRT patients were compared to age-matched non-RRT patients, with respect to the composition of the total $\mathrm{CD}^{+} \mathrm{T}$ cell population (Figure 1A) and differentiation of memory $\mathrm{CD} 4^{+} \mathrm{T}$ cells (Figure 1B).

Elderly, but not young, non-RRT patients had a more differentiated memory phenotype when compared to that of age-matched $\mathrm{HC}$ (Figure 1C) based on the percentage of CD28null memory T cells $(7.69 \pm 1.46 \%$ versus $3.83 \pm 0.49 \%, \mathrm{p}<0.05)$. RRT only resulted in a significant $(\mathrm{p}<0.05)$ higher percentage of $\mathrm{CD} 4{ }^{+} \mathrm{CD} 28$ null memory $\mathrm{T}$ cells in the young patient group (Figure $1 \mathrm{C}$ ).

\section{$\mathrm{CD}^{+} \mathrm{T}$ cell differentiation is increased and significantly different in the young RRT patients}

Compared to the $\mathrm{CD}^{+}{ }^{+} \mathrm{T}$ cell compartment, the number and differentiation of circulating $\mathrm{CD}^{+} \mathrm{T}$ cells was more affected in non-RRT patients. On average, absolute numbers of $\mathrm{CD}^{+} \mathrm{T}$ cells were lower compared to agematched $\mathrm{HC}$ which was largely attributable to a significant decrease in memory $\mathrm{T}$ cells in young non-RRT patients, and decreased naïve $\mathrm{T}$ cell numbers in the old non-RRT group (Figure 2A). Comparing old non-RRT patients to age-matched RRT patients revealed a slight but significantly $(\mathrm{p}<0.05)$ decreased number of naïve and memory $\mathrm{T}$ cells (Figure 2A).

The $\mathrm{CD}^{+}$memory $\mathrm{T}$ cell compartment of the young and old non-RRT groups consisted of significantly $(\mathrm{p}<0.01)$ less CM when compared to age-matched $\mathrm{HC}$, resulting in relatively more differentiated $\mathrm{CD}^{+} \mathrm{T}$ cells with a EM/EMRA phenotype (Figure $2 \mathrm{~B}$ ). The influence of RRT was only observed within the young RRT group. These younger patients receiving RRT showed an increased differentiation of the memory $\mathrm{CD}^{+} \mathrm{T}$ cell compartment, reflected by an increase in EMRA $\mathrm{T}$ cell numbers $(\mathrm{p}<0.01$, Figure $2 \mathrm{~B})$ compared to non-RRT patients. This finding was in accordance with the increased percentage of memory $\mathrm{CD}^{+} \mathrm{T}$ cells lacking CD28 on their cell surface as compared to the group of young non-RRT patients ( $\mathrm{p}<0.05$, Figure $2 \mathrm{C}$ ).

\section{Thymic output of $\mathrm{T}$ cells and relative telomere length of $\mathrm{CD}^{+}$and $\mathrm{CD}^{+}{ }^{+}$cells}

In young and old non-RRT patients a lower thymic $T$ cell output was shown by the significant lower TREC 
Table 1 Study population characteristics

\begin{tabular}{|c|c|c|c|c|c|c|}
\hline \multirow[b]{2}{*}{ Group } & \multicolumn{2}{|c|}{$\begin{array}{l}\text { End-stage renal disease patients not } \\
\text { receiving renal replacement therapy }\end{array}$} & \multicolumn{2}{|c|}{$\begin{array}{l}\text { End-stage renal disease patients } \\
\text { receiving renal replacement therapy }\end{array}$} & \multicolumn{2}{|c|}{ Healthy controls } \\
\hline & Young & Old & Young & Old & Young & Old \\
\hline Number of individuals & 22 & 33 & 49 & 49 & 55 & 65 \\
\hline Age in Years & $33.5 \pm 9.6^{*}$ & $64.4 \pm 6.3^{*}$ & $35.7 \pm 8.5^{*}$ & $63.1 \pm 8.7^{*}$ & $38.4 \pm 7.9^{*}$ & $63.5 \pm 7.5^{*}$ \\
\hline Male & $77.3 \%$ & $60.6 \%$ & $55.1 \%$ & $71.4 \%$ & $49.1 \%$ & $38.5 \%$ \\
\hline CMV positive & $54.5 \%$ & $51.2 \%$ & $59.2 \%$ & $53.1 \%$ & $50.9 \%$ & $49.2 \%$ \\
\hline Hemodialysis & & & 25 & 32 & & \\
\hline Peritoneal dialysis & & & 24 & 17 & & \\
\hline Duration of RRT (years) & & & $4.30(0.1-22)^{* *}$ & $2.76(0.2-18)^{* *}$ & & \\
\hline \multicolumn{7}{|l|}{ Underlying kidney disease } \\
\hline - Hypertensive nephropathy & $13.6 \%$ & $27.2 \%$ & $20.8 \%$ & $30.6 \%$ & & \\
\hline - Primary glomerulopathy & $31.8 \%$ & $18.2 \%$ & $18.8 \%$ & $18.4 \%$ & & \\
\hline - Diabetic nephropathy & $0 \%$ & $21.2 \%$ & $2.1 \%$ & $8.2 \%$ & & \\
\hline - Polycystic kidney disease & $9.1 \%$ & $9.0 \%$ & $0 \%$ & $2.0 \%$ & & \\
\hline - Reflux nephropathy & $18.2 \%$ & $3.0 \%$ & $14.6 \%$ & $4.1 \%$ & & \\
\hline - Other & $9.1 \%$ & $15.2 \%$ & $20.9 \%$ & $8.2 \%$ & & \\
\hline - Unknown & $18.2 \%$ & $6.0 \%$ & $22.9 \%$ & $28.6 \%$ & & \\
\hline
\end{tabular}

* Data are given in means with standard deviation.

** Data are given in means with range.

content of $\mathrm{T}$ cells compared to age-related $\mathrm{HC}$ (Figure 3A, $\mathrm{p}<0.05$ ) for comparison of the two lines. Using linear regression analysis for both $\mathrm{HC}$ as well as non-RRT patients, an average immunological age for a non-RRT patient with a calendar age of 40 years was estimated. For this purpose, the value for thymic output (deltaCt, TREC content) of this 40 year old patient was calculated using the formula for the regression line of non-RRT patients. This value was then plotted in the formula for the regression line of $\mathrm{HC}$ and resulted in an average calendar age of 46.6 years. The immunological age of the patient's $\mathrm{T}$ cells using thymic output was thus increased with approximately 7 years (Figure 3A), lines indicate the discrepancy between calendar ages of a nonRRT patient and a HC (i.e. the immunological age of the non-RRT patient), respectively. However, the TREC content was equally low for non-RRT and RRT patients (Figure 3B).

The relative telomere length (RTL) of $\mathrm{CD}^{+}$ (Figure $4 \mathrm{~A}$ ) as well as $\mathrm{CD}^{+} \mathrm{T}$ cells (Figure $4 \mathrm{C}$ ) decreased in both $\mathrm{HC}$ and non-RRT patients with increasing age, although these patients had or tendet to have shorter telomeres within both $\mathrm{CD}^{+} \mathrm{T}$ cells $(\mathrm{p}<0.05$, Figure $4 \mathrm{~A})$ and $\mathrm{CD}^{+} \mathrm{T}$ cells $(\mathrm{P}=0.07$, Figure $4 \mathrm{C}$ ) when compared to age-matched HC. Using regression analysis for these ageing parameters, as described above, the immunological age of a 40 -year old non-RRT patient amounted to approximately 60 years. A significant $(\mathrm{p}<0.05)$ lower RTL for $\mathrm{CD}^{+}$ $(11.17 \pm 0.74 \%$ versus $15.15 \pm 1.73 \%$, Figure $4 \mathrm{D})$, was found in the young RRT group when compared to the non-RRT group. No differences in RTL were observed for the $\mathrm{CD}^{+}{ }^{+} \mathrm{T}$ cells between RRT and non-RRT groups (Figure 4B).

\section{Discussion}

The results of this study show that based on several immunological parameters, ESRD without RRT is associated with premature immunological ageing of the $\mathrm{T}$ cell system. The added effect of RRT on this phenomenon is remarkably small and was predominantly limited to the $\mathrm{CD}^{+} \mathrm{T}$ cell compartment in young ESRD patients.

Most studies on the immune system of patients with renal failure have been performed in chronic ESRD patients treated with RRT, mainly hemodialysis. Lymphopenia and signs of $\mathrm{T}$ cell activation have been reported in a lot of the studies [16,17]. In-depth analysis of $\mathrm{T}$ cell subsets showed that lymphopenia is particularly prominent in the naïve $\mathrm{T}$ cell subset which showed a progressive decline in numbers as the stage of chronic kidney disease increased $[2,18]$. In a recent study, we showed that decreased numbers of naïve $\mathrm{T}$ cells in hemodialysis patients is related to decreased thymic output of naïve $\mathrm{T}$ cells with increased but insufficient homeostatic proliferation in the periphery [19]. Memory $\mathrm{T}$ cells were in general more differentiated probably due to increased proliferation, given the decrease in relative telomere length. Similar findings were now observed for ESRD patients not on dialysis, indicating that loss 


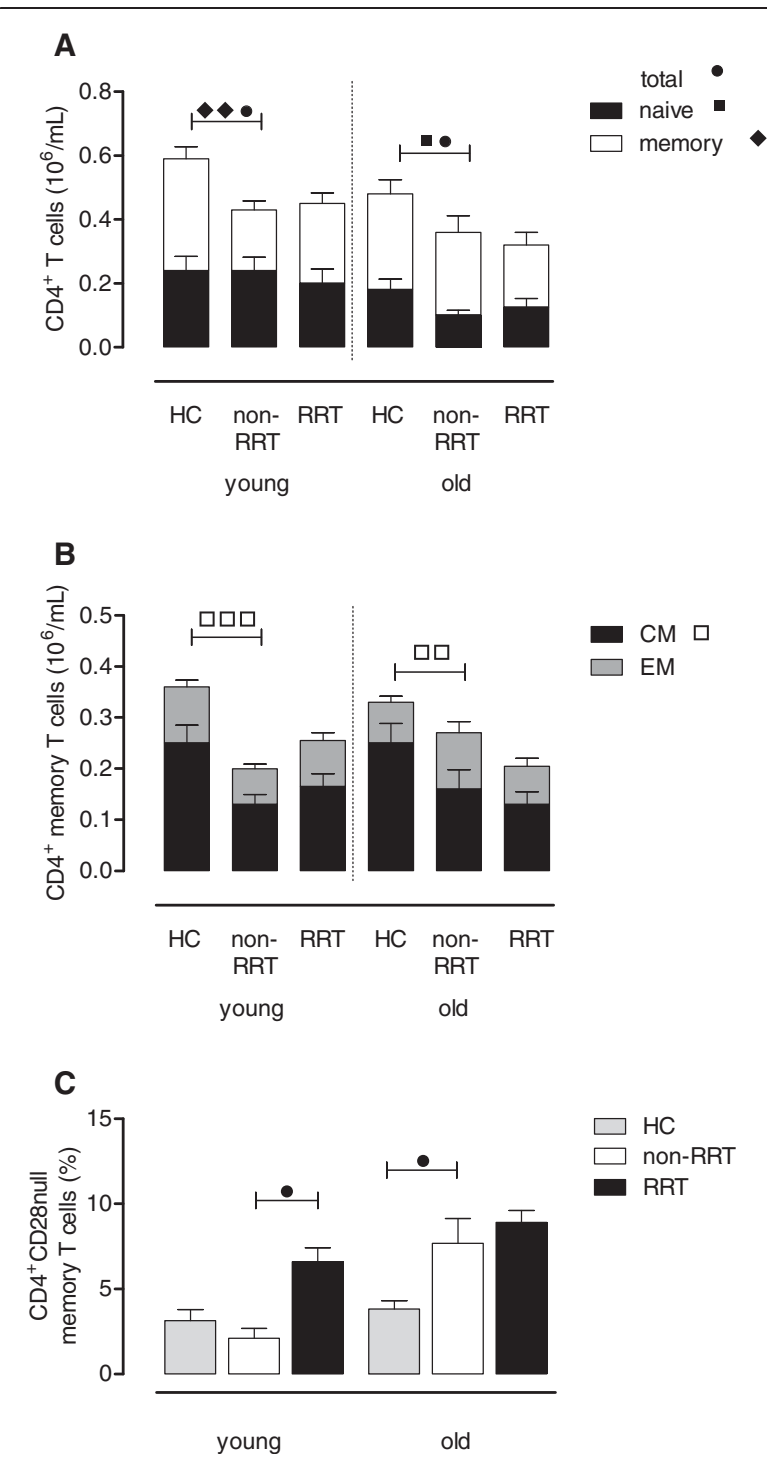

Figure $1 \mathrm{CD}^{+} \mathrm{T}$ cell phenotype and differentiation status.

Using a whole blood staining, the phenotype and differentiation status of $\mathrm{CD}^{+} \mathrm{T}$ cells were determined in $\mathrm{HC}$ and ESRD patients not on RRT or receiving RRT. The absolute number of $\mathrm{CD}^{+} \mathrm{T}$ cells of young (age: $<50$ years) and old (age: $\geq 50$ years) $\mathrm{HC}$ and these ESRD patients was dissected into a naïve (closed bars) and memory (open bars) compartment (A). Next, the composition of the memory compartment (CM in black and EM in grey bars) of $\mathrm{CD}^{+} \mathrm{T}$ cells is given for young and old HC and ESRD patients on RRT or not (B). In addition, we also determined the percentage memory $\mathrm{CD}^{+} \mathrm{T}$ cells lacking CD28 (i.e. CD28null) on their cell surface as another marker for T cell differentiation for HC (grey bars) and ESRD patients not on RRT (white bars) or receiving RRT (black bars) (C). Bars represent the means + SEM and statistically significant differences between the groups are shown (one symbol: $p<0.05$, two symbols: $p<0.01$, three symbols: $\mathrm{p}<0.001$ )

of renal function is the most dominant factor for decreased thymic output of naïve $\mathrm{T}$ cells and increased differentiation/proliferation of memory $\mathrm{T}$ cells. In healthy individuals these changes are observed in the

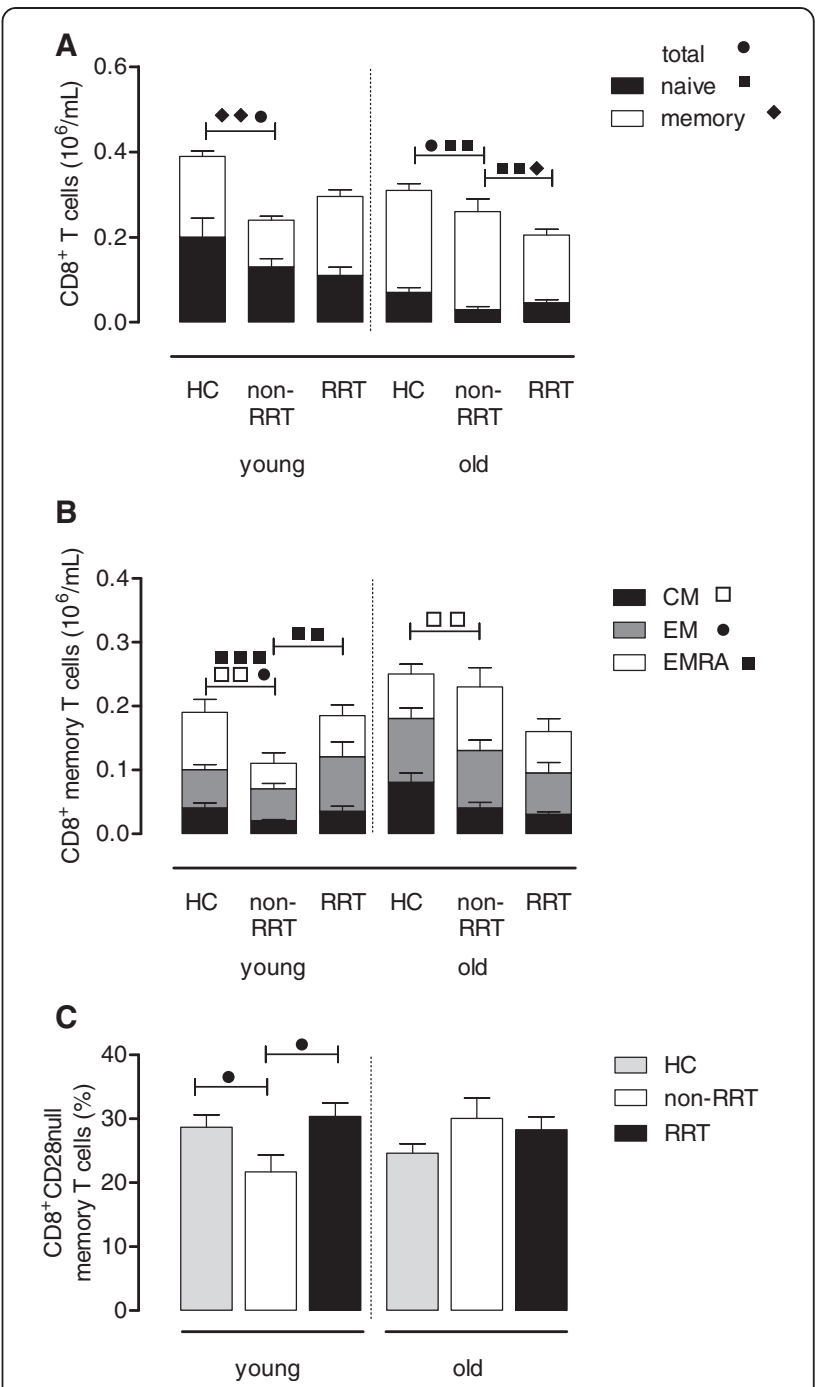

Figure $2 \mathrm{CD}^{+} \mathrm{T}$ cell phenotype and differentiation status. Using a whole blood staining, the phenotype and differentiation status of $\mathrm{CD}^{+} \mathrm{T}$ cells were determined in $\mathrm{HC}$ and ESRD patients not on RRT or receiving RRT. The absolute number of $C D 8^{+} T$ cells of young (age: $<50$ years) and old (age: $\geq 50$ years) $\mathrm{HC}$ and these ESRD patients was dissected into a naïve (closed bars) and memory (open bars) compartment (A). Next, the composition of the memory compartment (CM in black, EM in grey and EMRA in white bars) of $\mathrm{CD}^{+} \mathrm{T}$ cells is given for young and old $\mathrm{HC}$ and ESRD patients on RRT or not (B). In addition, we also determined the percentage memory $C D 8^{+} \mathrm{T}$ cells lacking CD28 (i.e. CD28null) on their cell surface as another marker for T cell differentiation for HC (grey bars) and ESRD patients not on RRT (white bars) or receiving RRT (black bars) (C). Bars represent the means + SEM and statistically significant differences between the groups are shown (one symbol: $p<0.05$, two symbols: $p<0.01$, three symbols: $p<0.001)$.

elderly and therefore considered as a physiological process of immunological ageing of the $\mathrm{T}$ cell system. In comparison to the $\mathrm{CD}^{+} \mathrm{T}$ cells, the $\mathrm{CD} 4^{+} \mathrm{T}$ cell system in healthy individuals remains relatively unaffected by age until the seventh or eighth decade [10,12,20-23]. However, patients with ESRD not on 


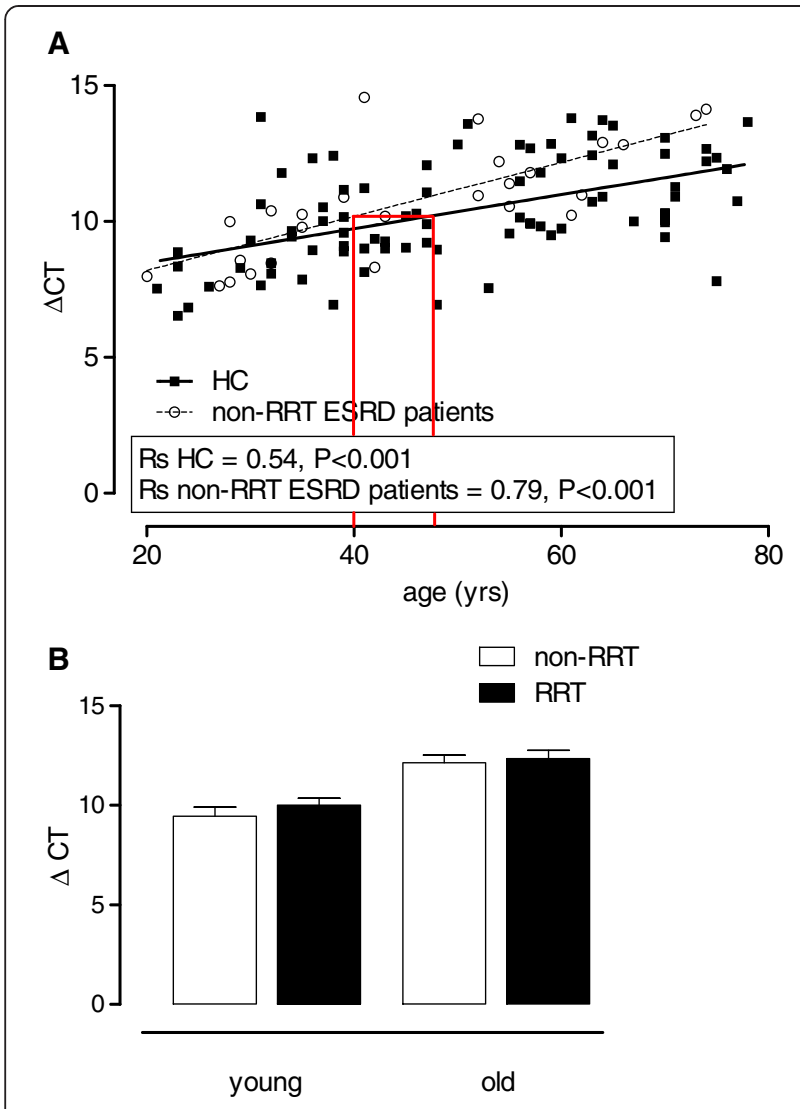

Figure 3 Quantification of the TREC content by quantitative PCR. The threshold cycle (Ct) is the number of amplification cycles needed to detect the TRECs and is a relative measure, inversely related with the concentration of TRECs. Control for DNA input was done by performing a quantitative PCR ( $\mathrm{PPCR}$ ) for albumin and the difference between the $\mathrm{Ct}$ for TRECS and the $\mathrm{Ct}$ for albumin was calculated $(\Delta \mathrm{Ct})$. The $\Delta \mathrm{Ct}$, indicative for TREC content, was determined of HC (straight line) and ESRD patients not on RRT (dotted line) and lines were compared using a linear regression analysis $(p<0.05$ for the difference between lines for ESRD patients not on RRT and HC). The lines in (A) mark the discrepancy between the calendar age (i.e. 40 years) of a non-RRT patient and the immunological age, by extrapolation of the value for the deltaCT (TREC content) to the $\mathrm{HC}$ regression line. In addition, Spearmans Rho correlation coefficients (Rs) were calculated for $\mathrm{HC}$ and ESRD patients not on RRT to determine the strength of the association between TREC content (calculated as $\Delta \mathrm{Ct}$ ) and age. Age is depicted on the $\mathrm{X}$-axis whereas on the $\mathrm{Y}$-axis the $\Delta \mathrm{Ct}$ value for TREC content is displayed. Next, the effect of RRT on the TREC content (B) was analyzed by dissecting the ESRD patients into a young ( $<50$ years) and old ( $\geq 50$ years) group and either not (white bars) or receiving (black bars) RRT. Bars represent means + SEM.

RRT already showed all characteristics of immunological ageing (lower thymic output, shorter telomeres) of their T cell system, approximately 10-20 years ahead of their calendar age. The reasons for premature $\mathrm{T}$ cell ageing in patients with chronic renal failure are not known but a relative lack of the $T$ cell growth factor IL-7 has been documented and may be important [1,2]. In animal models it was clear that sudden loss of renal function causes involution of the thymus and other lymphoid organs confirming a direct relationship between kidney function and lymphopoiesis [24]. Lymphopenia may trigger increased homeostatic proliferative responses [25], not only of the circulating naïve $\mathrm{T}$ cell compartment but also of memory $\mathrm{T}$ cells thereby inducing differentiation and loss of telomere length. However this concept is hypothetical and has not been tested yet in ESRD patients.

In general, immunological ageing of $\mathrm{T}$ cells (e.g. increased numbers of CD28null T cells) has been associated with decreased $\mathrm{T}$ cell immunity. Maintenance and generation of a number of antibody responses seems critically dependent on the presence of antigen-specific $\mathrm{CD} 4^{+} \mathrm{T}$ cells $[3,26]$. Any major disturbances of the $\mathrm{T}$ cell system will therefore affect the humoral immune response as well. ESRD-related premature immunological $T$ cell ageing may therefore underlie the well-established uremia-associated cellular and humoral immune deficiency in ESRD patients [1].

In a previous study, it was shown that loss of naïve $\mathrm{T}$ cells and increased memory $\mathrm{T}$ cell differentiation progresses with increasing stage of chronic kidney disease but with little difference between ESRD patients with or without RRT $[2,18]$. Also on the level of T cell chemokine receptor expression, which is indicative for functional capacities of $\mathrm{T}$ cells few differences were observed between T cells of ESRD patient with or without RRT. These findings are remarkable as most patients on dialysis have little to no residual renal function and as such are metabolically more affected than ESRD patient not on dialysis. The results in this study are largely in accordance with these data and show that patients with RRT do not have an altered thymic output of naïve $T$ cells and total numbers of naïve $\mathrm{T}$ cells. Summarizing the present data, it appears that the maximum effect of loss of renal function on the $\mathrm{T}$ cell immune system is reached at the level of ESRD. Whether RRT prevents further immunological ageing or not is difficult to assess and cannot be inferred from our data.

However, the $\mathrm{CD}_{4}^{+}$and $\mathrm{CD}^{+}$memory $\mathrm{T}$ cells in young dialysis patients showed more differentiation and in the $\mathrm{CD}^{+} \mathrm{T}$ cells this was accompanied by a decrease in RTL. Thus, particularly memory $\mathrm{CD}^{+} \mathrm{T}$ cells in younger patients show a history of more proliferation without the presence of decreased thymic output. This finding indicates that in younger dialysis patients, on top of ESRD-related immunological ageing, other factors drive the proliferation of memory $\mathrm{T}$ cells. The dialysis vintage of younger patients was on average higher than the old group suggesting a role for duration of RRT and loss of telomere length. However, we could not find an independent statistically significant relation between 

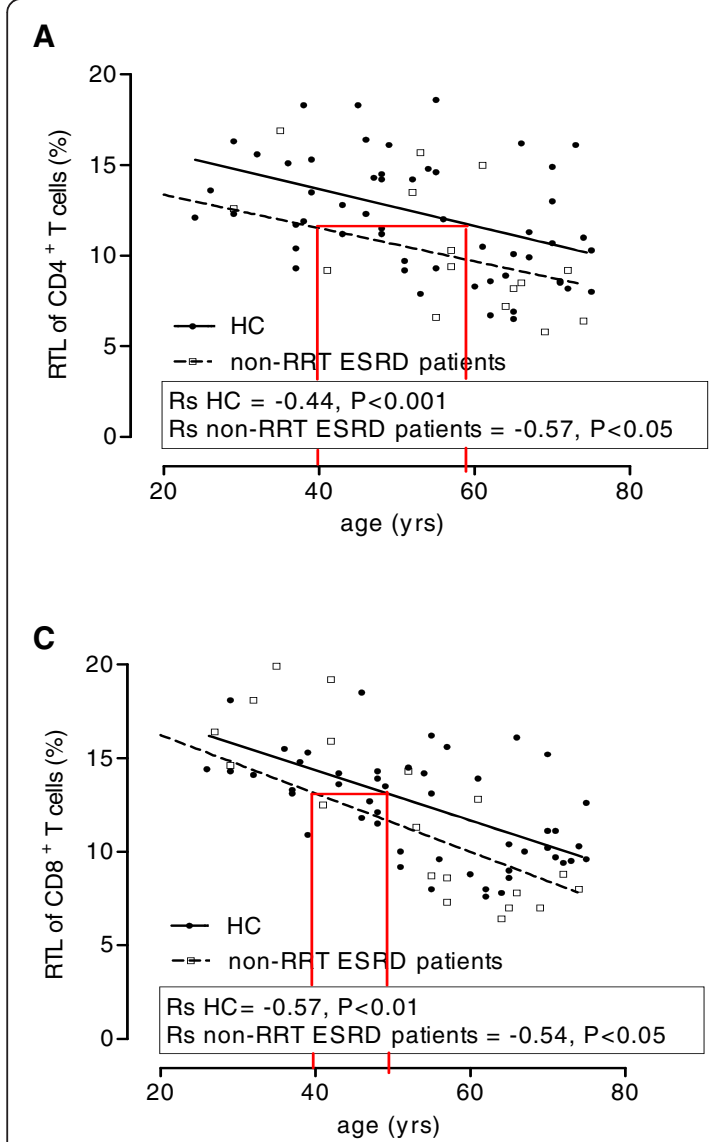

B

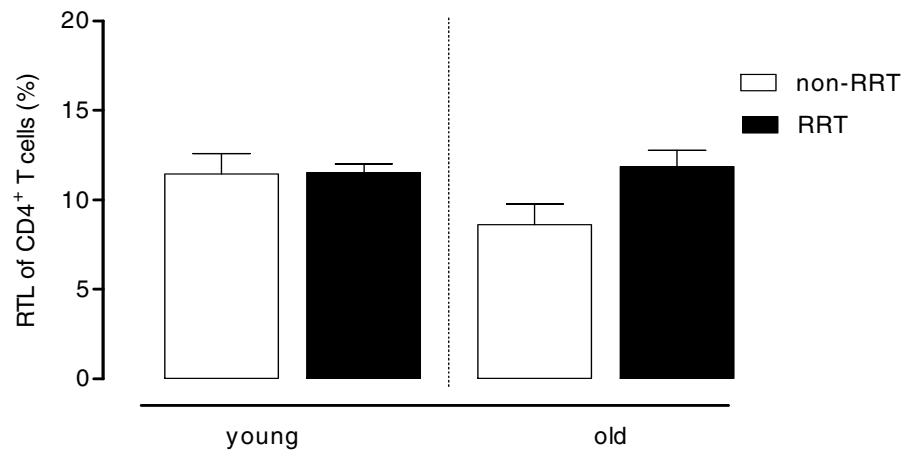

D

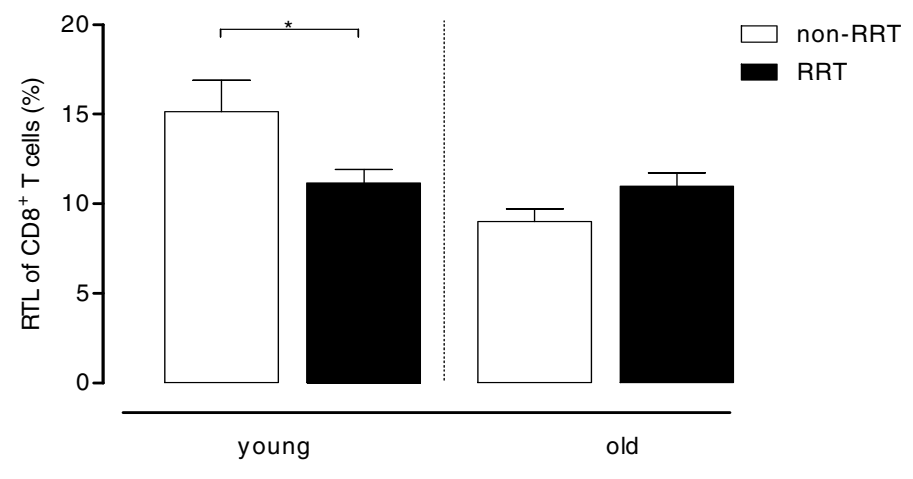

Figure 4 Relative telomere length of $\mathrm{CD}^{+}$and $\mathrm{CD}^{+} \mathbf{T}$ cells. The relative telomere length (RTL) of the $\mathrm{CD} 4^{+}(\mathbf{A})$ and $\mathrm{CD} 8^{+}(\mathbf{C}) \mathrm{T}$ cells is determined of HC (straight line) and ESRD patients not on RRT (dotted line) and lines were compared using a linear regression analysis i.e. $p<0.05$ and $p=0.07$ when comparing the differences between $\mathrm{HC}$ and non-RRT patients with respect to CD4 ${ }^{+}$RTL and CD $8^{+}$RTL respectively. The lines in $\mathrm{A}$ and $\mathrm{C}$ highlight the discrepancy between the calendar age (i.e. 40 years) of a non-RRT patient and the immunological age, by extrapolation of the value for the $\mathrm{CD}^{+}$and $\mathrm{CD} 8^{+} \mathrm{RTL}$ to the $\mathrm{HC}$ regression line, respectively. In addition, Spearmans Rho correlation coefficients (Rs) were calculated for HC and ESRD patients not on RRT to determine the strength of the association between RTL and age. Age is depicted on the X-axis and the RTL on the Y-axis. The effect of RRT on the RTL of CD4 ${ }^{+}(\mathbf{B})$ as well as CD8 ${ }^{+}$(D) T cells was analyzed by dissecting the ESRD patients into a young ( $<50$ years) and old ( $\geq 50$ years) group and either not receiving RRT (white bars) or receiving RRT (black bars). Bars represent means + SEM. Statistical differences between the groups are shown $\left({ }^{*} p<0.05\right)$.

duration of RRT and any of the immunological parameters measured. In addition, the type of underlying kidney diseases was not related to any parameter of immunological ageing. Another possible scenario may be that RRT actually improves homeostatic proliferation of memory $\mathrm{T}$ cells in the young but not in the elderly patients. However, this should result in a relative increase in memory $\mathrm{T}$ cell numbers in the young RRT patients compared to ESRD patients without RRT which was not observed. The lack of such a finding would argue against this explanation.

A limitation of the present study is the cross-sectional design which may obscure subtle changes in immunological $\mathrm{T}$ cell ageing after patients with ESRD have started RRT. However, the large number of patients included in this study adds to the reliability of the results.
In conclusion, severe loss of renal function leading to ESRD is a very potent inducer of premature immunological $\mathrm{T}$ cell ageing of both the $\mathrm{CD} 4^{+}$and $\mathrm{CD} 8^{+} \mathrm{T}$ cells. Renal replacement therapy is associated with a small increase of memory $\mathrm{T}$ cell ageing in patients $<50$ years of age, particularly in the $\mathrm{CD}^{+} \mathrm{T}$ cell subset. Further research is needed to establish the pathophysiology of ESRD-related $\mathrm{T}$ cell ageing and whether this can be reversed by e.g. interleukin-7 therapy $[27,28]$ or kidney transplantation.

\section{Methods}

\section{Study population}

ESRD patients were defined by a glomular filtration rate (GFR) of $\leq 15 \mathrm{ml} / \mathrm{min}$ and were either not on RRT or treated with hemodialysis or peritoneal dialysis. Patients having an infection, malignancy, autoimmune disease or 
a history of immunosuppressive drugs (including previous kidney transplantations) were excluded. Healthy individuals were included as controls. They were matched for age and cytomegalovirus (CMV) positivity, as these are well-known factors affecting the composition of the $\mathrm{T}$ cell compartment $[1,19]$. The clinical and demographic characteristics of the ESRD patients and $\mathrm{HC}$ are shown in Table 1. All individuals included gave informed consent and the local medical ethical committee approved the study (METC number: 2012-022). It was conducted according to the principles of Declaration of Helsinki and in compliance with International Conference on Harmonization/Good Clinical Practice regulations.

\section{Differentiation status of circulating $T$ cells}

$\mathrm{T}$ cell phenotype and differentiation status was analyzed as described previously [1,19]. Briefly, whole blood was stained with AmCyan labeled anti-CD3 (BD Biosciences, Erembodegem, Belgium) in combination with pacific blue labeled anti-CD4 (BD) or allophycocyanin Cy7 (APC-Cy7) labeled anti-CD8 (BD) to identify $\mathrm{CD}^{+}$or $\mathrm{CD}^{+} \mathrm{T}$ cells that are further dissected into four different subsets based on the expression of CCR7 and CD45RO using fluorescein isothiocyanate (FITC) labeled antiCCR7 (R\&D systems, Uithoorn, The Netherlands) and allophycocyanin (APC) labeled anti-CD45RO (BD). Naive T cells are $\mathrm{CCR}^{+}$and $\mathrm{CD} 45 \mathrm{RO}^{-}$, Central memory (CM) cells are $\mathrm{CCR}^{+}$and $\mathrm{CD}^{2} 5 \mathrm{RO}^{+}$, Effector memory (EM) cells are CCR7 ${ }^{-}$and $\mathrm{CD}^{4} 5 \mathrm{RO}^{+}$and EMRA cells are CCR7 ${ }^{-}$and CD45RO'.

$\mathrm{T}$ cell differentiation is associated with loss of CD28 expression on cell surface. Percentages of CD28 (or CD28null) $\mathrm{T}$ cells within the $\mathrm{T}$ cell subsets were determined by staining with peridinin chlorophyll-Cy5.5 (PerCP-Cy5.5) labeled anti-CD28 (BD).

\section{PBMC isolation}

Peripheral blood mononuclear cells (PBMC) were isolated from heparinized blood samples by Ficoll gradient centrifugation. In hemodialyis patients, the blood samples were drawn before a hemodialysis session [1]. Two million PBMC were snap-frozen for the TREC assay and the rest of the PBMC were frozen in liquid nitrogen with a minimum amount of $10 \times 10^{6}$ cells per vial for further experiments.

\section{DNA isolation and TREC assay}

TREC content was assessed using the snap-frozen PBMC. Briefly, DNA was isolated according to manufacturer's instructions (Qiagen Isolation kit, Qiagen, Venlo, the Netherlands). Subsequently, TREC content was determined using quantitative PCR. For this purpose, a combination of two primers and a hydrolysis probe specific for the so-called $\delta R E C(T C R D)-\psi J \alpha(T C R A)$ TREC (sjTREC) were employed. TaqMan quantitative PCR was performed on $50 \mathrm{ng}$ DNA in a $25 \mu \mathrm{l}$ reaction mixture containing $700 \mathrm{nmol} / \mathrm{l}$ of each primer 5'TCGTGAGAACGGTGAATGAAG-3' and 5'-CCATGC TGACACCTCTGGTT-3, $150 \mathrm{nmol} / \mathrm{l}$ of hydrolysis probe 5'(FAM) CACGGTGATGCATAGGCACCTGC-3' (TAMRA), and $12.5 \mu \mathrm{l} 2 \times$ TaqMan Universal PCR Master Mix (Applied Biosystems, Nieuwerkerk a/d IJssel, The Netherlands). Quantification of the DNA amount in each sample was performed using a quantitative PCR of the single-copy albumin gene. All reactions were performed in duplicate, unless a threshold cycle $(\mathrm{Ct})$ difference between replicates of $>1.5$ necessitated to repeat the PCR experiment. $\triangle \mathrm{Ct}$ was calculated by using the formula: $\mathrm{Ct}$ value TREC PCR - $\mathrm{Ct}$ value albumin PCR [13].

\section{Telomere length assay}

Flow fluorescent in situ hybridization was performed to determine the relative telomere length of $\mathrm{CD} 4^{+}$and $\mathrm{CD}^{+}$ $\mathrm{T}$ cells. For this purpose, the frozen PBMC were thawed and stained with either CD4-biotin (BeckmanCoulter, BV, Woerden, The Netherlands) or CD8-biotin (Biolegend, Europe BV, Uithoorn, the Netherlands) followed by staining with streptavidin-Cy5 (Biolegend). The PBMC were fixed and permeabilized (Invitrogen Life Technologies, Bleiswijk, The Netherlands) before the relative telomere length (RTL) was determined using the telomere PNA-kit/FITC (Zebra Bioscience BV, Enschede, The Netherlands). The sub cell line 1301 of CCRF-CEM, which is known to have long telomeres, was used to calculate the relative telomere length (RTL) of the $\mathrm{CD}^{+}$and $\mathrm{CD}^{+} \mathrm{T}$ cells $[1,29]$.

\section{Statistical analysis}

Patients not on RRT were compared to healthy controls on one hand and to patients receiving hemodialysis or peritoneal dialysis on the other hand using the MannWhitney test. For the TREC content and the RTL, a linear regression model was used to compare patients not on RRT to healthy controls. In addition, Spearman Rho correlation coefficients (Rs) were calculated to determine the strength of the association between the different ageing parameters and age for $\mathrm{HC}$ as well as ESRD patients not on RRT. All statistical tests were performed twosided and a p-value of $<0.05$, was considered significant.

\section{Competing interests}

All the authors declared no competing interests. This study was funded by the Dutch Kidney Foundation (KSPB.10.12).

\section{Authors' contributions}

RM: performed the experiments, statistical analysis and drafted the manuscript. NL: designed the study and drafted the manuscript. EdW: performed the experiments. AL: contributed in writing the manuscript. AvdS: 
performed some of the experiments. CB: contributed in writing the manuscript. WW: contributed in writing the manuscript and provided patient data. MB: designed the study and drafted the manuscript. All authors read and approved the final manuscript.

\section{Author details}

'Department of Internal Medicine, section Nephrology and Transplantation, Erasmus Medical Center, Rotterdam, the Netherlands. ${ }^{2}$ Transplantation, Erasmus Medical Center, Rotterdam, the Netherlands. ${ }^{3}$ Department of Immunology, Erasmus Medical Center, Rotterdam, the Netherlands.

Received: 27 July 2012 Accepted: 7 September 2012

Published: 12 September 2012

\section{References}

1. Betjes MG, Langerak AW, van der Spek A, de Wit EA, Litjens NH: Premature aging of circulating $T$ cells in patients with end-stage renal disease. Kidney Int 2011, 80:208-217.

2. Litjens NH, van Druningen CJ, Betjes MG: Progressive loss of renal function is associated with activation and depletion of naive T lymphocytes. Clin/mmunol 2006, 118:83-91.

3. Litjens NH, Huisman M, van den Dorpel M, Betjes MG: Impaired immune responses and antigen-specific memory CD4+ T cells in hemodialysis patients. J Am Soc Nephrol 2008, 19:1483-1490.

4. Verkade MA, de WJ V, Klepper M, Vaessen LM, Weimar W, Betjes MG: Peripheral blood dendritic cells and GM-CSF as an adjuvant for hepatitis B vaccination in hemodialysis patients. Kidney Int 2004, 66:614-621.

5. Vanholder R, Ringoir S: Infectious morbidity and defects of phagocytic function in end-stage renal disease: a review. J Am Soc Nephrol 1993, 3:1541-1554.

6. Maisonneuve P, Agodoa L, Gellert R, Stewart JH, Buccianti G, Lowenfels AB, Wolfe RA, Jones E, Disney AP, Briggs D, et al: Cancer in patients on dialysis for end-stage renal disease: an international collaborative study. Lancet 1999, 354:93-99.

7. Appay V, van Lier RA, Sallusto F, Roederer M: Phenotype and function of human T lymphocyte subsets: consensus and issues. Cytometry A 2008, 73:975-983.

8. Sallusto F, Geginat J, Lanzavecchia A: Central memory and effector memory T cell subsets: function, generation, and maintenance. Annu Rev Immunol 2004, 22:745-763.

9. Weinberger B, Lazuardi L, Weiskirchner I, Keller M, Neuner C, Fischer KH, Neuman B, Wurzner R, Grubeck-Loebenstein B: Healthy aging and latent infection with CMV lead to distinct changes in CD8+ and CD4+ T-cell subsets in the elderly. Hum Immunol 2007, 68:86-90.

10. Naylor K, Li G, Vallejo AN, Lee WW, Koetz K, Bryl E, Witkowski J, Fulbright J, Weyand CM, Goronzy JJ: The influence of age on T cell generation and TCR diversity. J Immunol 2005, 174:7446-7452.

11. Wikby A, Johansson B, Olsson J, Lofgren S, Nilsson BO, Ferguson F: Expansions of peripheral blood CD8 T-lymphocyte subpopulations and an association with cytomegalovirus seropositivity in the elderly: the Swedish NONA immune study. Exp Gerontol 2002, 37:445-453.

12. Wikby A, Mansson IA, Johansson B, Strindhall J, Nilsson SE: The immune risk profile is associated with age and gender: findings from three Swedish population studies of individuals 20-100 years of age. Biogerontology 2008, 9:299-308

13. Zubakov D, Liu F, van Zelm MC, Vermeulen J, Oostra BA, van Duijn CM, Driessen GJ, van Dongen JJ, Kayser M, Langerak AW: Estimating human age from T-cell DNA rearrangements. Curr Biol 2010, 20:R970-971.

14. lancu $E M$, Speiser $D E$, Rufer $N$ : Assessing ageing of individual $T$ lymphocytes: mission impossible? Mech Ageing Dev 2008, 129:67-78.

15. Lin J, Epel E, Cheon J, Kroenke C, Sinclair E, Bigos M, Wolkowitz O, Mellon S, Blackburn E: Analyses and comparisons of telomerase activity and telomere length in human $T$ and B cells: insights for epidemiology of telomere maintenance. J Immunol Methods 2010, 352:71-80.

16. Griveas I, Visvardis G, Fleva A, Papadopoulou D, Mitsopoulos E, Kyriklidou P, Manou E, Ginikopoulou E, Meimaridou D, Paulitou A, Sakellariou G: Comparative analysis of immunophenotypic abnormalities in cellular immunity of uremic patients undergoing either hemodialysis or continuous ambulatory peritoneal dialysis. Ren Fail 2005, 27:279-282.

17. Schollmeyer P, Bozkurt F: The immune status of the uremic patient: hemodialysis vs CAPD. Clin Nephrol 1988, 30(Suppl 1):S37-40.
18. Yoon JW, Gollapudi S, Pahl MV, Vaziri ND: Naive and central memory T-cell lymphopenia in end-stage renal disease. Kidney Int 2006, 70:371-376.

19. Litjens NH, de Wit EA, Betjes MG: Differential effects of age, cytomegalovirus-seropositivity and end-stage renal disease (ESRD) on circulating T lymphocyte subsets. Immun Ageing 2011, 8:2.

20. Olsson J, Wikby A, Johansson B, Lofgren S, Nilsson BO, Ferguson FG: Agerelated change in peripheral blood T-lymphocyte subpopulations and cytomegalovirus infection in the very old: the Swedish longitudinal OCTO immune study. Mech Ageing Dev 2000, 121:187-201.

21. Wikby A, Maxson P, Olsson J, Johansson B, Ferguson FG: Changes in CD8 and CD4 lymphocyte subsets, $T$ cell proliferation responses and nonsurvival in the very old: the Swedish longitudinal OCTO-immune study. Mech Ageing Dev 1998, 102:187-198.

22. Wikby A, Nilsson BO, Forsey R, Thompson J, Strindhall J, Lofgren S, Ernerudh J, Pawelec G, Ferguson F, Johansson B: The immune risk phenotype is associated with IL-6 in the terminal decline stage: findings from the Swedish NONA immune longitudinal study of very late life functioning. Mech Ageing Dev 2006, 127:695-704.

23. Strindhall J, Nilsson BO, Lofgren S, Ernerudh J, Pawelec G, Johansson B Wikby A: No Immune Risk Profile among individuals who reach 100 years of age: findings from the Swedish NONA immune longitudinal study. Exp Gerontol 2007, 42:753-761.

24. Raskova J, Czerwinski DK, Shea SM, Raska K Jr: Cellular immunity and lymphocyte populations in developing uremia in the rat. J Exp Pathol 1986, 2:229-245.

25. Datta S, Sarvetnick N: Lymphocyte proliferation in immune-mediated diseases. Trends Immunol 2009, 30:430-438.

26. Litjens NH, Huisman M, Hijdra D, Lambrecht BM, Stittelaar KJ, Betjes MG: IL-2 producing memory $\mathrm{CD} 4+\mathrm{T}$ lymphocytes are closely associated with the generation of IgG-secreting plasma cells. J/mmunol 2008, 181:3665-3673.

27. Fry TJ, Connick E, Falloon J, Lederman MM, Liewehr DJ, Spritzler J, Steinberg SM, Wood LV, Yarchoan R, Zuckerman J, et al: A potential role for interleukin-7 in T-cell homeostasis. Blood 2001, 97:2983-2990.

28. Schluns KS, Kieper WC, Jameson SC, Lefrancois L: Interleukin-7 mediates the homeostasis of naive and memory CD8 T cells in vivo. Nat Immunol 2000, 1:426-432

29. Hultdin M, Gronlund E, Norrback K, Eriksson-Lindstrom E, Just T, Roos G: Telomere analysis by fluorescence in situ hybridization and flow cytometry. Nucleic Acids Res 1998, 26:3651-3656.

doi:10.1186/1742-4933-9-19

Cite this article as: Meijers et al:: Uremia causes premature ageing of the T cell compartment in end-stage renal disease patients. Immunity \& Ageing 2012 9:19.

\section{Submit your next manuscript to BioMed Central and take full advantage of:}

- Convenient online submission

- Thorough peer review

- No space constraints or color figure charges

- Immediate publication on acceptance

- Inclusion in PubMed, CAS, Scopus and Google Scholar

- Research which is freely available for redistribution 